\section{Gooseberry Mite Infestation Decreases the Cold Hardiness of Dormant Black Currant Flower Buds}

\author{
John Carter ${ }^{1}$ \\ Department of Horticultural Science, University of Minnesota, 1970 Folwell \\ Avenue, St. Paul, MN 55108-6007 \\ Kim E. Hummer ${ }^{2}$ \\ U.S. Department of Agriculture, Agricultural Research Service, National Clonal \\ Germplasm Repository, 33447 Peoria Road, Corvallis, OR 97333-2521
}

Additional index words. Ribes nigrum, Cecidophyopsis grossulariae, abiotic and biotic stress, cold tolerance, ice nucleation, freeze damage

\begin{abstract}
Black currant (Ribes nigrum L.) cultivars with heavy, light, and no gooseberry mite (Cecidophyopsis grossulariae Collinge) infestation levels (MIL) were tested for cold hardiness by visually determining the bud injury rating (BIR) after laboratory freezing in Jan. 1998. Lightly mite-infested cvs. Blackdown and Risager, usually thought of as less cold hardy than Nordic cultivars, survived $-35^{\circ} \mathrm{C}$, while mite-infested buds of the Finnish cv. Brödtorp were injured at $-35^{\circ} \mathrm{C}$. Heavily mite-infested buds of the Swedish $R$. nigrum $\mathrm{L}$. cv. StorKlas from Corvallis, Ore., were injured at $-20^{\circ} \mathrm{C}$ while lightly infested buds were injured to $-25^{\circ} \mathrm{C}$. Noninfested 'StorKlas' buds from Pennsylvania and British Columbia survived laboratory freezing to $-35{ }^{\circ} \mathrm{C}$. Heavy mite infestation lowered the bud cold hardiness of 'Brödtorp' and 'StorKlas' by $10^{\circ} \mathrm{C}$, as estimated by a modified SpearmanKarber $T_{50}$, relative to the hardiness of lightly mite-infested buds of these cultivars. Heavily mite-infested buds contained unusual tissues forming what appeared to be spherical blisters or eruptions, $\approx 100 \mu$ in diameter. Other tissues in the region of heavy mite infestation appeared to be more turgid than their noninfested counterparts. Abiotic and biotic stresses can have a combined impact on field-grown black currants.
\end{abstract}

In mid-Dec. 1997, a severe infestation of the gooseberry mite was observed in the Ribes field planting at the U.S. Dept. of Agriculture, Agricultural Research Service, National Clonal Germplasm Repository in Corvallis, Ore. The identity of the mite was confirmed through morphological (Amrine et al., 1994) and molecular tests (Fenton et al., 1993). The mite was observed within dormant buds of $>50$ genotypes of $R$. nigrum L., $R$. rubrum L., $R$. uva-crispa L., R. oxyacanthoides L., and R. $\times$ nidigrolaria Bauer (unpublished data). Mite infestation levels were genotype dependent; some cultivars were heavily infested but others were not.

Gooseberry mite infestation could affect the cold hardiness of the dormant buds. Interaction between pathogenic and environmental

Received for publication 17 Apr. 1998. Accepted for publication 6 Oct. 1998. Research sponsored by Minnesota Agricultural Experiment Station, Univ. of Minnesota Bush Sabbatical Supplement Program and USDA-ARS CRIS 5350-21000-022-00D. We greatly appreciate the donation of plant material from Ed Mashburn, Northumberland, Pa., and Richard McGinnis, Courtenay, B.C., and thank Les Fuchigami and Tony Chen for use of laboratory equipment at the Dept. of Horticulture, Oregon State Univ. The cost of publishing this paper was defrayed in part by the payment of page charges. Under postal regulations, this paper therefore must be hereby marked advertisement solely to indicate this fact. ${ }^{1}$ Professor.

${ }^{2}$ Research Leader/Curator. stresses to woody plants has been reported. The reduction of freezing tolerance of woody plants by microbial infection has been documented in peach [Prunus persica (L.) Batsch.] (Daniell and Krewer, 1984; Chang et al., 1989) and apple (Malus $\times$ domestica Borkh.) (Zawadzka, 1988). Noninjurious freezing stress can predispose woody plants, such as dogwood (Cornus stolonifera Michx. ) and Euonymus alatus (Thunb.) Sieb., to infection by canker-causing bacteria (Schoeneweiss, 1979; Schoeneweiss and Wene, 1977). In red raspberry (Rubus idaeus L.), freezing injury was increased by previous damage from twospotted spider mite (Tetranychus urticae Koch) (Doughty et al., 1972). The objective of our study was to determine the effect of gooseberry mite infestation on the bud cold hardiness of several black currant cultivars.

\section{Materials and Methods}

Four black currant cultivars with a range of mite infestation levels (MIL) and cold hardiness ratings were chosen for laboratory freezing. Western European currant cultivars are generally much less winter hardy than their Nordic counterparts (Brennan, 1996). The English 'Blackdown' and the German 'Risager', which had low levels of mite infestation, were chosen for these reasons. The Swedish 'StorKlas' and Finnish 'Brödtorp', two cultivars generally regarded as very cold hardy (Brennan, 1996; Trajkovski, 1991), which were heavily mite-infested in the Corvallis field collection, were also chosen. In addition, dormant stems of 'StorKlas' without mite infestation were obtained from Pennsylvania and British Columbia, Canada. Cold hardiness was assessed by rating the bud injury of these cultivars after laboratory freezing trials during Jan. 1998.

The first laboratory trial (Expt. 1) contrasted freezing damage of heavily infested buds of 'StorKlas' and 'Brödtorp' with that of lightly infested buds of 'Blackdown' and 'Risager.' In an additional trial (Expt. 2), freezing injury of noninfected 'StorKlas' buds from Pennsylvania and British Columbia were contrasted with heavily and lightly mite-infested buds of Oregon-grown 'StorKlas.'

Expt. 1. Because each bud was differentially infested with mites, buds were considered as experimental units. On 8, 14, and 26 Jan. 1998 , stem sections, each containing at least four buds, were collected for each cultivar. Each section was placed in a plastic bag and labeled by cultivar and test temperature. The bags were placed in an insulated container and were transported to the Oregon State Univ. campus. The sample bags were placed in a programmable air-chest freezer set at $2{ }^{\circ} \mathrm{C}$. The air temperature was lowered $5^{\circ} \mathrm{C}$ per $\mathrm{h}$ during the freezing trial. One bag of each cultivar was removed when the freezer reached $-15,-20,-25,-30$, and $-35^{\circ} \mathrm{C}\left( \pm 0.4^{\circ} \mathrm{C}\right)$ and transferred to $\mathrm{a} 4^{\circ} \mathrm{C}$ refrigerator. After $16 \mathrm{~h}$ the bags were removed from the refrigerator and were placed in open storage at $26^{\circ} \mathrm{C}$ for $7 \mathrm{~d}$ to allow injury symptoms to develop.

Buds were visually examined individually by dissection under a binocular microscope ( $\times 60$ to 80 ). A BIR and MIL between 1 and 10 was determined for each bud. The BIR scale was: $1=$ no damage; 2 to $4=$ only outer bud scales damaged; 5 to $7=$ bud still alive but some damage to one set of inflorescences; 8 to $9=$ all flowers in one set of inflorescences dead, some leaf scales alive; $10=$ inflorescences and leaf scales dead. Values of BIR $\leq 7$ were considered nonlethal, $>7$, lethal. The MIL scale was: $1=$ no mites; 2 to $4=<50$ mites in outer bud scales; 5 to $7=50$ to 99 mites within the bud, some on leaf scales; 8 to $9=$ 100 to 500 mites within the bud, many on inner surfaces of leaf scales; $10=>500$ mites in every region including inflorescences. Values of 7 or below were considered light infestation, MIL > 7, heavy.

Expt. 2. Nodal stem sections of 'StorKlas' and 'Brödtorp' were collected from Corvallis, Ore., as described above. At least four sections, each containing at least four buds, were frozen for each test temperature on 8,14 , or 26 Jan. Samples of 'Blackdown' and 'Risager' were collected from Corvallis, Ore., and similarly frozen on 8 Jan. Because all of the Corvallis, Ore., 'StorKlas' buds had mites, noninfested buds were collected in Pennsylvania and British Columbia, and shipped to Corvallis by overnight mail. Three stem sections from Pennsylvania and four from British Columbia were frozen to $-35^{\circ} \mathrm{C}$ on $26 \mathrm{Jan}$. Because Corvallis-grown mite-infested 'StorKlas' and 'Brödtorp' buds showed dam- 
age before the freezing tests, initial BIR was determined. On 22 Jan., nodal samples of heavily mite-infested 'StorKlas' and 'Brödtorp' were collected and rated without laboratory freezing to determine baseline BIR.

To quantify the cold hardiness differential between heavily and lightly mite-infested buds, a modified Spearman-Karber $\mathrm{T}_{50}$ test statistic (Bittenbender and Howell, 1974) was applied to data from 'Brödtorp' frozen on 14 Jan. and 'StorKlas' frozen on 26 Jan.

\section{Results and Discussion}

Black currant buds with heavy mite infestation contained unusual tissues forming what appeared to be spherical blisters or eruptions, $\approx 100 \mu$ in diameter. Other tissues in the region of heavy mite infestation appeared more turgid than their noninfested counterparts. The BIR of nonfrozen, heavily mite-infested 'Brödtorp' was 2.9; that of 'StorKlas' was 4.3 (Table 1). The results of the 8 Jan. freezing trial indicated that the "expected least cold hardy" cultivars, 'Blackdown' and 'Risager', did not suffer lethal bud damage at $-35^{\circ} \mathrm{C}$ (Table 2); however, the mite-infested 'Brödtorp' and 'StorKlas' showed freezing damage at -35 and $-25^{\circ} \mathrm{C}$, respectively (Table 2), more than the BIR due to MIL alone (Table 1). These results suggest that mite infestation decreased the cold hardiness of 'Brödtorp' and 'StorKlas'; however, no noninfested buds of these cultivars were available from Corvallis and had to be obtained from other locations. 'StorKlas' was available from central Pennsylvania, where winter minima are lower than that of Corvallis. Because this more severe climate could induce additional cold hardiness, 'StorKlas' samples were also obtained from the maritime climate of Vancouver Island, B.C. The 'StorKlas' buds from neither Pennsylvania nor British Columbia had mites, and the sample buds of each remained undamaged by laboratory freezing to $-35^{\circ} \mathrm{C}$ (Table 3 ). Thus, these noninfested buds were more cold hardy than the infested 'StorKlas' buds from Corvallis, Ore. (Tables 2 and 3 ).

To quantify the differential bud injury for light and heavy mite infestation within a cul-

Table 1. Number of buds examined, and mean bud injury ratings $\mathrm{s}^{\mathrm{z}}(\mathrm{BIR})$ and mean mite infestation levels ${ }^{y}$ (MIL), with SD, of nonfrozen black currant cvs. Brödtorp and StorKlas harvested from Corvallis, Ore., on 22 Jan. 1998.

\begin{tabular}{lccc}
\hline \hline Cultivar & $\begin{array}{l}\text { No. buds } \\
\text { examined }\end{array}$ & BIR (SD) & MIL (SD) \\
\hline Brödtorp & 28 & $2.9(2.5)$ & $8.8(1.8)$ \\
StorKlas & 34 & $4.3(3.1)$ & $9.0(1.2)$ \\
\hline
\end{tabular}

${ }^{2}$ BIR of $1=$ no damage; 2 to $4=$ only outer bud scales damaged; 5 to $7=$ bud still alive but some damage to one set of inflorescences; 8 to $9=$ all flowers in one set of inflorescences dead, some leaf scales alive; 10 $=$ inflorescences and leaf scales dead. BIR $\leq 7$ were considered nonlethal; BIR $>7$, lethal.

${ }^{\mathrm{y}} 1=$ no mites; 2 to $4=<50$ mites, in outer bud scales; 5 to $7=50$ to 99 mites in bud, some on leaf scales; 8 to $9=100$ to 500 mites in bud, many on inner surfaces of leaf scales; $10=>500$ mites in bud, in every region including on inflorescences. MIL $\leq 7$ were considered light infestation; MIL > 7, heavy. tivar, a Spearman-Karber $\mathrm{T}_{50}$ test statistic (Bittenbender and Howell, 1974) was applied to the data for 'Brödtorp', frozen on 14 Jan., and 'StorKlas', frozen on 26 Jan. These data were chosen because sufficient numbers of heavily and lightly infested buds were available at the test temperatures. The data were adjusted by reducing the percentage of dead buds due to initial MIR, as presented in Table 1. The heavily mite-infested buds of 'Brödtorp' and 'StorKlas' had $\mathrm{T}_{50}$ values $\approx 10{ }^{\circ} \mathrm{C}$ higher than those that were lightly mite-infested (Table 4).

In conclusion, two heavily mite-infested cultivars, 'Brödtorp' and 'StorKlas', which were normally very cold hardy, were less cold hardy than the lightly infested cultivars 'Blackdown' and 'Risager' from the same location. Second, heavily mite-infested buds of 'StorKlas' were less hardy than lightly infested buds of this cultivar from Corvallis, Ore., and both were less hardy than noninfested buds of 'StorKlas' from Pennsylvania or British Columbia. Third, heavy mite infestation reduced the cold hardiness level for 'Brödtorp' and 'StorKlas' by $\approx 10^{\circ} \mathrm{C}$ as determined by Spearman-Karber $\mathrm{T}_{50}$ analysis.

This study demonstrates that gooseberry mite infestation can alter the response of black currants to low-temperature stress. This con-

Table 2. Number of buds examined, test temperature, and mean bud injury ratings ${ }^{2}$ (BIR) and mean mite infestation levels $\mathrm{y}$ (MIL), with SD, for black currant cvs. Brödtorp, StorKlas, Blackdown, and Risager, collected from Corvallis, Ore., and frozen in the laboratory on 8 Jan. 1998.

\begin{tabular}{lcccr}
\hline \hline \multirow{4}{*}{ Cultivar } & $\begin{array}{c}\text { No. buds } \\
\text { examined }\end{array}$ & $\begin{array}{c}\text { Test } \\
\text { temperature } \\
\left({ }^{\circ} \mathrm{C}\right)\end{array}$ & BIR (SD) & MIL (SD) \\
\hline Brödtorp & 10 & -35 & $6.5(2.9)$ & $8.4(1.6)$ \\
& 5 & -30 & $3.8(1.2)$ & $7.8(1.0)$ \\
& 5 & -25 & $2.2(1.6)$ & $8.4(1.4)$ \\
& 5 & -20 & $2.2(1.6)$ & $10.0(0.0)$ \\
StorKlas & 6 & -15 & $3.8(3.0)$ & $7.8(0.4)$ \\
& 7 & -35 & $8.9(0.8)$ & $9.6(0.7)$ \\
& 5 & -30 & $8.4(0.5)$ & $10.0(0.0)$ \\
& 5 & -25 & $8.0(0.0)$ & $10.0(0.0)$ \\
Blackdown & 7 & -20 & $3.6(3.1)$ & $8.0(0.9)$ \\
& 7 & -15 & $6.8(2.5)$ & $10.0(0.0)$ \\
& 5 & -35 & $1.4(0.8)$ & $4.4(1.2)$ \\
Risager & 5 & -30 & $3.2(2.2)$ & $3.6(2.5)$ \\
& 5 & -25 & $1.0(0.0)$ & $2.2(1.0)$ \\
& 5 & -20 & $1.0(0.0)$ & $4.6(0.8)$ \\
& 4 & -35 & $2.5(0.9)$ & $1.5(0.9)$ \\
& 4 & -30 & $1.5(0.9)$ & $1.0(0.0)$ \\
& 5 & -25 & $1.0(0.0)$ & $1.0(0.0)$ \\
& 5 & -20 & $1.2(0.4)$ & $1.0(0.0)$ \\
\hline
\end{tabular}

${ }^{\mathrm{z}}$ See footnote $\mathrm{z}$, Table 1 .

${ }^{\mathrm{y}}$ See footnote $\mathrm{y}$, Table 1 .

Table 3. Number of buds examined, test temperature, and mean bud injury ratings ${ }^{\mathrm{z}}(\mathrm{BIR})$ and mean mite infestation levels ${ }^{y}$ (MIL), with SD, of black currant cv. StorKlas collected from Corvallis, Ore.; Northumberland, Pa.; and Courtenay, B.C.; frozen on 26 Jan. 1998.

\begin{tabular}{lcccr}
\hline \hline & $\begin{array}{c}\text { Test } \\
\text { No. buds } \\
\text { examined }\end{array}$ & $\begin{array}{c}\text { temperature } \\
\left({ }^{\circ} \mathrm{C}\right)\end{array}$ & BIR (SD) & MIL (SD) \\
\hline Oregon & 26 & -35 & $8.8(1.7)$ & $8.3(2.8)$ \\
& 22 & -30 & $8.5(2.0)$ & $7.4(3.4)$ \\
& 25 & -25 & $8.4(1.4)$ & $8.4(2.0)$ \\
& 27 & -20 & $8.6(2.3)$ & $7.4(3.2)$ \\
British Columbia & 24 & -15 & $9.5(0.8)$ & $6.1(3.2)$ \\
Pennsylvania & 12 & -35 & $1.0(0.0)$ & $1.0(0.0)$ \\
& 12 & -35 & $1.0(0.0)$ & $1.0(0.0)$ \\
\hline
\end{tabular}

${ }^{2}$ See footnote $\mathrm{z}$, Table 1 .

${ }^{y}$ See footnote y, Table 1. clusion parallels the observation of other pathoKrewer 1984), apples (Zawadzka 1988), dogwood (Schoeneweiss, 1979; Schoeneweiss and Wene, 1977), and red raspberries (Doughty et al., 1972). However, in these examples, and resulted in reduced starch and sugar reserves, tion to any indirect effects, we suspect that the gooseberry mite infestation within the dormant currant buds has a direct component; presence and the physiological changes, the mites, increase the number of ice nucleation sites, thus reducing the ability of buds to supercool and thereby avoid freezing injury.

The means by which gooseberry mites decrease the freezing tolerance of black curthe underlying mechanism, these observations support the more general conclusion that a combination of biotic and abiotic stresses in the field can have a synergistic, negative impact on plant winter survival. was indirect. The two-spotted mitc caused premature defoliation or damage to the photosynthetic tissue during the summer and 1972). rant buds will be investigated further. What- 
Table 4. Spearman-Karber $\mathrm{T}_{50}{ }^{\mathrm{z}}$ with variances $(\mathrm{S})$ for heavily and lightly mite-infested buds ${ }^{y}$ of black currant $\mathrm{cv}$. Brödtorp, collected and tested on 14 Jan. 1998, and R. nigrum cv. StorKlas, tested on 26 Jan. 1998. These samples from Corvallis, Ore., were frozen in the laboratory to $-15,-20,-25,-30$, and $-35^{\circ} \mathrm{C}$ and were visually rated for bud injury.

\begin{tabular}{lccccc}
\hline & \multicolumn{4}{c}{ Mite infestation } \\
\cline { 2 - 3 } \cline { 5 - 6 } Cultivar & \multicolumn{2}{c}{ Heavy } & & \multicolumn{2}{c}{ Light } \\
\cline { 2 - 3 } \cline { 5 - 6 } & $\mathrm{T}_{50}$ & $\mathrm{~S}$ & & $\mathrm{~T}_{50}$ & $\mathrm{~S}$ \\
\hline Brödtorp & -25.7 & 1.7 & & -35.2 & 2.0 \\
StorKlas & -23.1 & 1.4 & & -33.0 & 4.6
\end{tabular}

${ }^{\mathrm{z}}$ Spearman-Karber $\mathrm{T}_{50}$ and variances were calculated separately for the heavily and lightly infested buds of each cultivar. Because not all buds survived the highest test temperature, a $\mathrm{T}_{0}$ of $-10{ }^{\circ} \mathrm{C}$ was assumed; the lowest test temperature did not kill all buds, thus a $\mathrm{T}_{\mathrm{L}}$ of $-40^{\circ} \mathrm{C}$ was assumed (Bittenbender and Howell, 1974).

${ }^{\mathrm{y}}$ Heavy infestation was defined as $\geq 100$ and light infestation as $<100$ mites per bud.

\section{Literature Cited}

Amrine, J.W., G.H. Duncan, A.T. Jones, S.C. Gordon, and I.M. Roberts. 1994. Cecidophyopsis mites (Acari: Eriophyidae) on Ribes spp. (Grossulariaceae). Intl. J. Acarol. 20:139-168.

Bittenbender, H.C. and G.S. Howell. 1974. Adaptation of the Spearman-Karber method for estimating the $\mathrm{T}_{50}$ of cold stressed flower buds. J. Amer. Soc. Hort. Soc. 99:187-190.

Brennan, R. 1996. Currants and gooseberries, p. 191-295. In: J. Janick and J. Moore (eds.). Advances in fruit breeding. Purdue Univ. Press, West Lafayette, Ind

Chang, L.S., A. Iezzoni, G. Adams, and G.S. Howell. 1989. Leucostoma persoonii tolerance and cold hardiness among diverse peach genotypes. J. Amer. Soc. Hort. Sci. 114:482-485.

Daniell, J.W. and G.W. Krewer. 1984. Effect of number of bacteria on cold injury of rooted cuttings from phony-infected and uninfected peach trees. HortScience 19:423-424.

Doughty, C.C., P.C. Crandall, and C.H. Shanks, Jr. 1972. Cold injury to red raspberries and the effect of premature defoliation and mite damage. J. Amer. Soc. Hort. Sci. 97:670-673.

Fenton, T., G. Malloch, R.M. Brennan, A.T. Jones, S.C. Gordon, W.J. McGavin, and A.N.E. Birch. 1993. Taxonomic evaluation of three reputed species of Cecidophyopsis mites on Ribes. Acta Hort. 352:535-538.

Schoeneweiss, D.F. 1979. Protection against stress predisposition to Botryosphaeria canker in containerized Cornus stolonifera by soil injection with benomyl. Plant Dis. Rptr. 63:896900

Schoeneweiss, D.F. and E.G. Wene. 1977. Freezing stress predisposes Euonymus alatus stems to attack by Nectria cinnababina. Plant Dis. Rptr. 61:921-925.

Trajkovski, V. 1991. Currant and gooseberry breeding (in Swedish), p. 41-45. In: 1990-1991 Report, The Swedish Univ. Agr. Sci. Balsgard, Sweden.

Zawadzka, B. 1988. The influence of virus and mycoplasma diseases on frost damage of apple trees. Acta Hort. 235:59-67. 